\title{
Desulfoluna spongiiphila sp. nov., a dehalogenating bacterium in the Desulfobacteraceae from the marine sponge Aplysina aerophoba
}

\author{
Correspondence \\ Max M. Häggblom \\ haggblom@aesop.rutgers.edu
}

\section{Young-Beom Ahn, ${ }^{1} \dagger$ Lee J. Kerkhof ${ }^{2}$ and Max M. Häggblom ${ }^{1}$}

\author{
${ }^{1}$ Department of Biochemistry and Microbiology and Biotechnology Center for Agriculture and the \\ Environment, The State University of New Jersey, New Brunswick, NJ, USA \\ ${ }^{2}$ Institute for Marine and Coastal Sciences, Rutgers, The State University of New Jersey, New \\ Brunswick, NJ, USA
}

\begin{abstract}
A reductively dehalogenating, strictly anaerobic, sulfate-reducing bacterium, designated strain $\mathrm{AA} 1^{\top}$, was isolated from the marine sponge Aplysina aerophoba collected in the Mediterranean Sea and was characterized phenotypically and phylogenetically. Cells of strain $A A 1^{\top}$ were Gramnegative, short, curved rods. Growth of strain $A A 1^{\top}$ was observed between 20 and $37{ }^{\circ} \mathrm{C}$ (optimally at $28{ }^{\circ} \mathrm{C}$ ) at $\mathrm{pH} 7-8$. $\mathrm{NaCl}$ was required for growth; optimum growth occurred in the presence of $25 \mathrm{~g} \mathrm{NaCl} \mathrm{I}^{-1}$. Growth occurred with lactate, propionate, pyruvate, succinate, benzoate, glucose and sodium citrate as electron donors and carbon sources and either sulfate or 2-bromophenol as electron acceptors, but not with acetate or butyrate. Strain $A A 1^{\top}$ was able to dehalogenate several different bromophenols, and 2- and 3-iodophenol, but not monochlorinated or fluorinated phenols. Lactate, pyruvate, fumarate and malate were not utilized without an electron acceptor. The $\mathrm{G}+\mathrm{C}$ content of the genomic DNA was $58.5 \mathrm{~mol} \%$. The predominant cellular fatty acids were $\mathrm{C}_{14: 0}$, iso- $\mathrm{C}_{14: 0}, \mathrm{C}_{14: 0} 3-\mathrm{OH}$, anteiso- $\mathrm{C}_{15: 0}, \mathrm{C}_{16: 0}, \mathrm{C}_{16: 1} \omega 7 c$ and $\mathrm{C}_{18: 1} \omega 7 c$.

Phylogenetic analysis based on 16S rRNA gene sequence comparisons placed the novel strain within the class Deltaproteobacteria. Strain $A A 1^{\top}$ was related most closely to the type strains of Desulfoluna butyratoxydans (96\% 16S rRNA gene sequence similarity), Desulfofrigus oceanense (95\%) and Desulfofrigus fragile (95\%). Based on its phenotypic, physiological and phylogenetic characteristics, strain $A A 1^{\top}$ is considered to represent a novel species of the genus Desulfoluna, for which the name Desulfoluna spongiiphila sp. nov. is proposed. The type strain is $\mathrm{AA} 1^{\top}\left(=\mathrm{DSM} 17682^{\top}=\right.$ ATCC BAA $\left.-1256^{\top}\right)$.
\end{abstract}

The marine environment is a particularly rich source of biogenic organohalides, which are produced by a diversity of marine organisms, including molluscs, algae, polychaetes, jellyfish and sponges (Ashworth \& Cormier, 1967; Baker \& Duke, 1973; Fielman et al., 1999; Garson et al., 1994; Schmitz \& Gopichand, 1978; White \& Hager, 1977).

tPresent address: Division of Microbiology, National Center for Toxicological Research, US Food and Drug Administration, Jefferson, AR 72079-9502, USA.

Abbreviations: 2BP, 2-bromophenol; APS, adenosine 5'-phosphosulfate; DGGE, denaturing gradient gel electrophoresis; TRF, terminal restriction fragment; T-RFLP, terminal restriction fragment length polymorphism.

The GenBank/EMBL/DDBJ accession number for the $16 \mathrm{~S}$ rRNA gene sequence of strain $A A 1^{\top}$ is $E F 187256$.

T-RFLP electrophoregrams of sponge enrichments on bromophenols compared with pure culture of strain $A A 1^{\top}$ and fatty acid profiles of strain $A A 1^{\top}$ and related Desulfoluna and Desulfofrigus strains are available as supplementary material with the online version of this paper.
A number of sponges (phylum Porifera), such as species of the genus Aplysina, have been shown to produce a wide variety of brominated metabolites, including bromoindoles, bromophenols, polybrominated diphenyl ethers and brominated dibenzo-p-dioxins (Ebel et al., 1997; Gribble, 1999; Norte \& Fernández, 1987; Utkina et al., 2001). Brominecontaining metabolites can account for over $10 \%$ of the sponge dry weight (Turon et al., 2000). These compounds may serve as a chemical defence against predators and may inhibit biofouling (Weiss et al., 1996). In addition, Aplysina sponges harbour large amounts of bacteria, which can amount to $40 \%$ of the biomass of the animal, and it has been hypothesized that some of the organobromine compounds may in fact be synthesized by bacteria associated with the sponge (Hentschel et al., 2001, 2003).

As the marine environment is a particularly rich source of biogenic organohalides, it is not surprising that dehalogenating bacteria have been isolated from marine environments. Two dehalogenating bacteria in the genus 
Desulfovibrio were isolated by using halophenols as electron acceptors (Boyle et al., 1999, Sun et al., 2000). Sun et al. (2000) isolated a halobenzoate-dehalogenating Desulfomonile limimaris strain from marine sediments. Propionigenium maris, isolated from bromophenol-producing worms, is capable of debrominating 2,4,6-tribromophenol to 4-bromophenol (Steward et al., 1995; Watson et al., 2000).

We have previously demonstrated that the sponge Aplysina (synonym Verongia) aerophoba, which produces a brominated tyrosine derivative, harbours anaerobic, reductively dehalogenating bacteria (Ahn et al., 2003). From Aplysina sponge material, we maintained stable anaerobic enrichment cultures by using lactate as an electron donor and bromophenols as electron acceptors. Through metabolic and terminal restriction fragment length polymorphism (T-RFLP) analysis, the enrichments were found to consist of several types of organisms, including dehalogenating organisms. Here, we describe a novel sulfidogenic organism isolated from the sponge A. aerophoba that is capable of reductively dehalogenating brominated phenols and is able to couple reductive dehalogenation to growth by using lactate as an electron donor.

Aplysina aerophoba sponges were collected by scuba diving at the Marine Biological Station, Banyuls sur Mer, France, in April 2001. Primary anaerobic enrichment cultures were established with lactate as both electron donor and carbon source and with bromophenols as electron acceptors as described by Ahn et al. (2003). Anaerobic medium was prepared as described by Ahn et al. (2003). For enrichment of dehalogenating bacteria, we prepared dehalogenating medium by omitting $\mathrm{Na}_{2} \mathrm{SO}_{4}$ and adding $2.5 \mathrm{mM}$ lactate as electron donor. Periodically, we added $200 \mu \mathrm{M}$ 2-bromophenol (2BP) as the sole electron acceptor. For preparation of sulfidogenic medium, we added $20 \mathrm{mM}$ sulfate and $2.5 \mathrm{mM}$ lactate. The agar shake tube method (Breznak \& Costilow, 1994) was used for isolation. The medium was solidified with Noble agar (10 $\mathrm{g} \mathrm{l}^{-1}$; Difco). After three transfers of the original enrichment culture (total dilution of $\left.10^{-9}\right)$, a portion of the culture was serially diluted in agar shake culture tubes and incubated in the dark at $28{ }^{\circ} \mathrm{C}$. After 2 weeks, individual colonies were picked and transferred to liquid medium and cultivated to check for dehalogenating activity. We retrieved four cultures showing 2BP-dehalogenating activity. One of these, designated strain $\mathrm{AAl}^{\mathrm{T}}$, was selected for further study, and colonies were re-isolated in agar shake dilution cultures to ensure purity.

T-RFLP analysis and denaturing gradient gel electrophoresis (DGGE) were used to check the make-up of the purified culture. Total DNA was extracted from the cultures and the 16S rRNA gene was amplified by PCR using universal primers (fluorescently labelled 27F and 1525R) (Ahn et al., 2003). The amplified product was digested with restriction enzyme $M n l I$ and the 5 '-labelled terminal restriction fragment (TRF) was analysed with an ABI310 sequencer (Applied Biosystems) with GENESCAN software. DGGE was performed with a D gene system (Bio-Rad Laboratories) as described previously (Ahn et al., 2003).

Cells were harvested after growth in anaerobic sulfate-free medium for microscopic observations. Gram staining was performed following the protocols of Murray et al. (1994). Cell morphology was observed by using a phase-contrast microscope and epifluorescence microscope (Olympus BX 60 ) after staining with $0.1 \%$ acridine orange and was visualized with an oil-immersion objective (UPlanF1 100/ 1.3). Cells were observed by transmission electron microscopy after primary fixing for $3 \mathrm{~h}$ in Karnovsky's fixative (combination of low concentration of both formaldehyde and glutaraldehyde in $0.1 \mathrm{M}$ Milloning's phosphate buffer, pH 7.3) (Hayt, 1981). Post-fixation was carried out in $1 \%$ osmium tetroxide buffer for $1 \mathrm{~h}$ followed by dehydration in a graded ethanol series and embedding in an Epon/Araldite mixture. Thin sections were prepared by using a diamond knife and LKB-2088 ultramicrotome (LKB - Produkter). Thin sections were stained with $5 \%(\mathrm{w} / \mathrm{v})$ uranyl acetate solution in $50 \%$ ethanol for $15 \mathrm{~min}$ and then with $0.5 \%$ lead citrate solution in $\mathrm{CO}_{2}$-free double-distilled water (Reynold's lead citrate stain) for $2 \mathrm{~min}$. Micrographs were taken with a JEM-100CXII electron microscope (JEOL) (Bozzola \& Russell, 1992). To prepare samples for scanning electron microscopy, cells were transferred onto a polycarbonate membrane. Primary and post-fixation were carried as described above. After dehydration in a graded ethanol series, filters with cells were critical-point dried (Balzers CPD 020) and sputter coated (Balzers SCD 004). Micrographs were taken with an AMRAY-18301 scanning electron microscope (Bozzola \& Russell, 1992).

For the following experiments, $1 \%(\mathrm{v} / \mathrm{v})$ inoculum from an actively dehalogenating culture grown on lactate and $2 \mathrm{BP}$ was used after washing with anaerobic medium. To test the range of halogenated compounds used as electron acceptors, 3-bromophenol, 4-bromophenol, 2,6-dibromophenol, 2,4,6-tribromophenol, 2-chlorophenol, 3-chlorophenol, 4-chlorophenol, 2-iodophenol, 2-bromobenzoate, 3-bromobenzoate or 4-bromobenzoate (all at a minimum $98 \%$ purity; Sigma-Aldrich) were added at $200 \mu \mathrm{M}$ to sulfate-free anaerobic medium. Sulfate, sulfite and thiosulfate were tested as electron acceptors at $2.5 \mathrm{mM}$ with lactate as the electron donor. To test the utilization of a range of electron donors, acetate, propionate, fumarate, malate, butyrate, lactate, pyruvate, succinate, benzoate, glucose or sodium citrate were added at $2.5 \mathrm{mM}$ to the medium containing either $2.5 \mathrm{mM}$ sulfate or $200 \mu \mathrm{M} 2 \mathrm{BP}$ as the sole electron acceptor. To study the effect of sulfate on dehalogenation of $2 \mathrm{BP}, 2.5 \mathrm{mM}$ sulfate was added to anaerobic medium containing $200 \mu \mathrm{M} 2 \mathrm{BP}$ and electron donors. Before complete consumption of sulfate, the concentration of $2 \mathrm{BP}$ was measured to calculate reductive dehalogenation activity. Cultures were monitored periodically for the transformation of electron acceptors by using HPLC and ion chromatography. The optimum temperature for growth of cells was tested at 4, 10, 16, 
28, 30 and $37{ }^{\circ} \mathrm{C}$, and the optimum $\mathrm{NaCl}$ concentration for growth was tested at $0,10,15$ and $25 \mathrm{~g} \mathrm{l}^{-1}$.

The DNA G $+\mathrm{C}$ content was determined by using HPLC as described by Mesbah et al. (1989). Nucleosides were analysed by using a model 1100 series chromatograph (Agilent Technologies), with a reversed-phase C18 column (Partisil ODS-3, $4.6 \times 250 \mathrm{~mm}$, particle size $5 \mu \mathrm{m}$; Whatman) and a solvent of phosphate/methanol $(90: 10)$, and absorbance was monitored at $254 \mathrm{~nm}$. Phosphate buffer ( $\mathrm{pH} 4.0$ ) was prepared by dissolving $\mathrm{KH}_{2} \mathrm{PO}_{4}$ $(0.049 \mathrm{M})$ in distilled water and adjusting the $\mathrm{pH}$ with $85 \% \mathrm{H}_{3} \mathrm{PO}_{4}$.

Phenol and halogenated aromatic compounds were analysed by HPLC (1100 series; Agilent) with a C18 column (Spherisorb, $4.6 \times 250 \mathrm{~mm}$, particle size $5 \mu \mathrm{m}$;

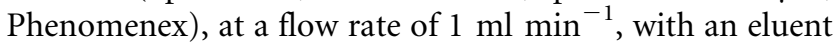
of methanol/water/acetic acid $(40: 58: 2)$ and a UV detector set to $280 \mathrm{~nm}$ (Ahn et al., 2003). Organic acids were analysed by HPLC (LC-10AS; Shimadzu Corp.) with an HPX-87H column (Bio-Rad) at $60{ }^{\circ} \mathrm{C}$, at a flow rate of $0.6 \mathrm{ml} \mathrm{min}{ }^{-1}$, with an eluent of $0.004 \mathrm{mM}$ sulfuric acid and a UV detector set to $210 \mathrm{~nm}$. Ion chromatography (Dionex DX-120) with an Ion Pac AS9 column was used for measurement of sulfate, sulfite and thiosulfate by using conductivity detection (Boyle et al., 1999; Monserrate \& Häggblom, 1997). Protein yield as a cell growth indicator was measured by the Bradford method (Bradford, 1976). Briefly, 10-ml cultures were centrifuged and resuspended in $500 \mu \mathrm{l}$ phosphate buffer (50 mM, pH 7.0). Cells were lysed in a boiling water bath with $0.1 \mathrm{M} \mathrm{NaOH}$ for 10 min and the sample was neutralized with $\mathrm{HCl}$ prior to analysis.

Cellular lipids from strain $\mathrm{AA}^{\mathrm{T}}$ grown on sulfate-free medium were saponified, methylated and extracted into hexane/methyl tertiary butyl ether as described by Song et al. (2001). Fatty acid methyl esters were analysed via GC by using the SHERLOCK Microbial Identification System (MIDI), and identification was verified by GC-MS with an Agilent series 6890 GC system and 5973 mass-selective detector, equipped with an HP5 MS capillary column (30 $\mathrm{m} \times 0.25 \mathrm{~mm}$ inner diameter, film thickness, $0.25 \mu \mathrm{m}$ ) with helium as the carrier gas.

DNA was extracted as described previously (Ahn et al., 2003) and was used for cloning and sequencing of $16 \mathrm{~S}$ rRNA genes. The 16S rRNA gene was amplified with universal primers (27F and 1525R) (Lane, 1991) and was cloned by using the TOPO TA cloning kit (Invitrogen). Clones were sequenced with a BigDye fluorescent dye terminator sequencer (Perkin Elmer). Internal primers of conserved regions of the 16S rRNA gene sequence (Lane, 1991) were used for sequencing. The dissimilatory adenosine $5^{\prime}$-phosphosulfate (APS) reductase genes (aprBA) were amplified with primers AprA-1-FW (5' TGGCAGATCATGATYMAYGG), AprA-10-RV (5' -CKGWAGTAGWARCCRGGRTA) (Meyer \& Kuever, 2007), APS7b-F (5'-GGYCTSTCCGCYATCAAY) and APS8-R (5'-GCACATGTCGAGGAAGTCTTC) (Friedrich, 2002) by using the following reaction conditions: $1 \mathrm{~min}$ at $95{ }^{\circ} \mathrm{C}, 40$ cycles of $1 \mathrm{~min}$ at $95{ }^{\circ} \mathrm{C}, 1 \mathrm{~min}$ at $54{ }^{\circ} \mathrm{C}$ and $90 \mathrm{~s}$ at $72{ }^{\circ} \mathrm{C}$ and a final extension of $10 \mathrm{~min}$ at $72{ }^{\circ} \mathrm{C}$. Completed sequences were compiled and compared with entries in GenBank by using BLASTN (Altschul et al., 1997). Sequences were aligned with CLUSTAL X (Thompson et al., 1997) and $1300 \mathrm{bp}$ of unambiguously aligned sequence was used for phylogenetic analysis. A phylogenetic tree was created via the NEIGHBOR program by using the distance matrix (DNADIST) and maximum-likelihood (DNAML) method with programs in the PHYLIP package (Felsenstein, 1993). Bootstrap values were calculated with SEQBOOT and the tree was generated by using the programs NEIGHBOR and CONSENSE (Felsenstein, 1993).

A 2BP-dehalogenating culture was enriched from an $A$. aerophoba sponge sample by using lactate as electron donor and $2 \mathrm{BP}$ as electron acceptor. The dehalogenating culture was serially diluted in agar shake tubes and incubated until colonies developed. It took 2 weeks for colonies (diameter $<0.5 \mathrm{~mm}$ ) to appear. Twenty separate colonies were picked and transferred directly into anaerobic medium. Four of these showed 2BP-dehalogenating activity in liquid culture assays. These cultures were serially diluted in agar shake tubes until pure cultures were obtained. T-RFLP analysis showed that the final purified culture contained only one peak with a TRF of 196 bp (see Supplementary Fig. S1 in IJSEM Online). TRF 196 was observed in the original 2BP-dehalogenating enrichment (Ahn et al., 2003) as a major peak. DGGE analysis revealed a single band, the sequence of which exactly matched that of the isolate (data not shown). The 16S rRNA genes of four separate isolates were sequenced and were found to be identical to the PCR product. One of these isolates, designated strain $\mathrm{AAl}^{\mathrm{T}}$, was selected for further study.

Cells of strain $\mathrm{AAl}^{\mathrm{T}}$ were Gram-negative, slightly curved rods, approximately $1 \times 4 \mu \mathrm{m}$ (Fig. 1 ). Motility was not observed. Rod-shaped cells were observed in early phases of growth but were observed less frequently in older cultures. In stationary-phase cultures, long and curved rods were observed. Spores were not detected in 2-week-old cultures. When grown under optimal conditions with $2.5 \mathrm{mM}$ lactate and $200 \mu \mathrm{M} 2 \mathrm{BP}$, subcultures $(1 \%$, v/v, inoculum from an early stationary-phase culture) usually reached stationary phase within $4-5$ days. Strain $\mathrm{AAl}^{\mathrm{T}}$ grew at temperatures up to $37^{\circ} \mathrm{C}$, with optimum growth occurring at $28{ }^{\circ} \mathrm{C}$.

Propionate, lactate, pyruvate, succinate, citrate, benzoate and glucose $\left(2.5 \mathrm{mM}\right.$ each) were used by strain $\mathrm{AAl}^{\mathrm{T}}$ as electron donors with either sulfate or $2 \mathrm{BP}$ as electron acceptors (Table 1). Acetate accumulated in the medium during growth with lactate as the electron donor and sulfate or $2 \mathrm{BP}$ as electron acceptor. Acetate or butyrate $(2.5 \mathrm{mM})$ were not used by strain $\mathrm{AAl}^{\mathrm{T}}$ and utilization of lactate, pyruvate, fumarate or malate was not observed in the absence of an electron acceptor. Sulfate, sulfite and thiosulfate $(2.5 \mathrm{mM})$ as electron acceptors supported 


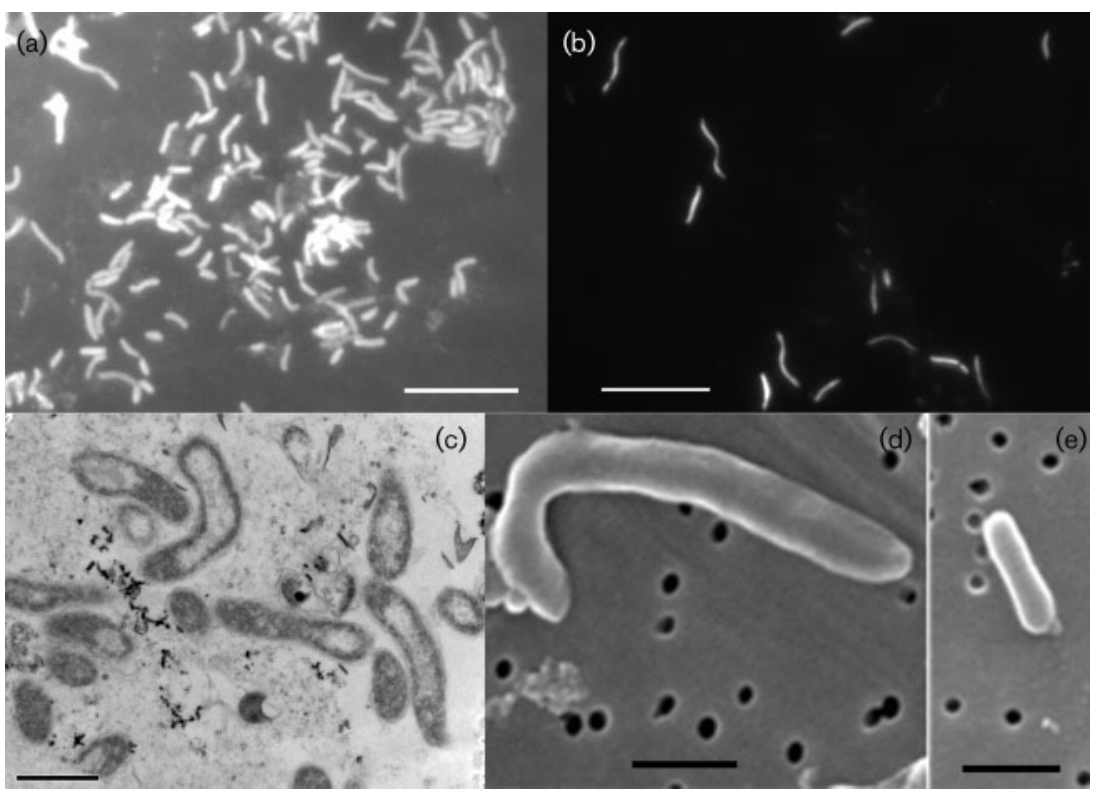

Fig. 1. Micrographs of cells of strain $A A 1^{\top}$. (a, b) Photomicrographs of cells grown with 2bromophenol and lactate; (c) transmission electron micrograph of young cells; $(d, e)$ scanning electron micrographs of old (10 days) (d) and young (1-2 days) (e) cells. Bars, $10 \mu \mathrm{m}(\mathrm{a}, \mathrm{b})$ and $1 \mu \mathrm{m}(\mathrm{c}-\mathrm{e})$.

Table 1. Characteristics of strain $A A 1^{\top}$ and type strains of related Desulfoluna and Desulfofrigus species

Strains: 1, strain AA1 ${ }^{\mathrm{T}} ; 2$, Desulfoluna butyratoxydans $\mathrm{MSL}^{\mathrm{T}}{ }^{\mathrm{T}}$ (data from this study unless indicated); 3 , Desulfofrigus oceanense ASv26 ${ }^{\mathrm{T}}$ (data from Knoblauch et al., 1999); 4, Desulfofrigus fragile LSv21 ${ }^{\mathrm{T}}$ (Knoblauch et al., 1999). The Desulfofrigus strains were cultivated at 4 or $10{ }^{\circ} \mathrm{C}$. ND, Not determined/no data available. All strains stained Gram-negative. Desulfoviridins were not detected. Utilization of electron donors was tested with sulfate as electron acceptor (and, for strain $\mathrm{AAl}^{\mathrm{T}}$, also with $2 \mathrm{BP}$ ). All strains utilized lactate, pyruvate and malate. None of the strains utilized propionate or succinate. Sulfate was used by all strains as electron acceptor.

\begin{tabular}{|c|c|c|c|c|}
\hline Characteristic & 1 & 2 & 3 & 4 \\
\hline Source & Marine sponge & Estuarine sediment ${ }^{\star}$ & Arctic marine sediment & Arctic marine sediment \\
\hline Cell morphology & Curved rods & Curved rods ${ }^{\star}$ & Thick rods & Slightly curved rods \\
\hline \multicolumn{5}{|l|}{ Cell size $(\mu \mathrm{m})$} \\
\hline Width & 1 & $0.8-0.9^{\star}$ & 2.1 & 0.8 \\
\hline Length & $2-4$ & $1.6-3.4^{*}$ & $4.2-6.1$ & $3.2-4.2$ \\
\hline $\begin{array}{l}\text { Optimum } \mathrm{NaCl} \text { concentration for } \\
\text { growth }(\%)\end{array}$ & 2.5 & $2.0^{*}$ & $1.5-2.5$ & $1.0-2.0$ \\
\hline Temperature optimum/range $\left({ }^{\circ} \mathrm{C}\right)$ & $28 / 10-36$ & $30 / \mathrm{ND}^{*}$ & $10 / 1.8-16$ & $18 / 1.8-27$ \\
\hline \multicolumn{5}{|l|}{$\begin{array}{l}\text { Utilization of electron donors } \\
(2.5 \mathrm{mM})\end{array}$} \\
\hline Acetate & - & - & + & - \\
\hline Fumarate & - & - & - & + \\
\hline Butyrate & - & + & + & + \\
\hline Formate & + & + & $\mathrm{ND}$ & ND \\
\hline Citrate & + & - & $\mathrm{ND}$ & ND \\
\hline Glucose & + & - & $\mathrm{ND}$ & ND \\
\hline \multicolumn{5}{|l|}{ Utilization of electron acceptors } \\
\hline 2,6-Dibromophenol $(200 \mu \mathrm{M})$ & + & - & $\mathrm{ND}$ & $\mathrm{ND}$ \\
\hline Thiosulfate $(2.5 \mathrm{mM})$ & + & + & + & - \\
\hline Sulfite $(2.5 \mathrm{mM})$ & + & + & + & - \\
\hline DNA G $+C$ content $(\mathrm{mol} \%)$ & 58.5 & $62^{*}$ & 52.8 & 52.1 \\
\hline Isoprenoid quinone & ND & $\mathrm{MK}-8\left(\mathrm{H}_{4}\right)^{*}$ & MK-9 & MK-9 \\
\hline
\end{tabular}

${ }^{\star}$ Data from Suzuki et al. (2008). 
grow in oxidized medium. The DNA $\mathrm{G}+\mathrm{C}$ content of strain $\mathrm{AAl}^{\mathrm{T}}$ was $58.5 \mathrm{~mol} \%$ (Table 1 ).

Phylogenetic analysis of the 16S rRNA gene sequence placed strain $\mathrm{AAl}^{\mathrm{T}}$ as a member of the class Deltaproteobacteria (Fig. 2). Strain $\mathrm{AAl}^{\mathrm{T}}$ was related most closely to Desulfoluna butyratoxydans MSL71 ${ }^{\mathrm{T}}$ (96\%16S rRNA gene sequence similarity of 1489 bp compared), Desulfofrigus oceanense ASv26 ${ }^{\mathrm{T}}$ (95\% of $1522 \mathrm{bp}$ compared) and Desulfofrigus fragile LSv $21^{\mathrm{T}}$ (95\% of $1520 \mathrm{bp}$ compared). The phylogeny predicted from the dissimilatory APS reductase genes ( $a p r B A)$ was generally in agreement with that predicted from 16S rRNA gene sequences (data not shown). The aprBA gene sequence of strain $\mathrm{AA} 1^{\mathrm{T}}$ was related closely to those of Desulfofrigus sp. HRS-La3x (GenBank accession no. EF442924; $93 \%$ similarity of 1545 bp compared) (Meyer \& Kuever, 2007) and Desulfofrigus oceanense DSM $12341^{\mathrm{T}}$ (AF418145; $92 \%$ of 891 bp compared) (Friedrich, 2002). The aprBA gene sequence of Desulfoluna butyratoxydans MSL7 $1^{\mathrm{T}}$ was not available and could not be included in the comparison. Based on this phylogenetic analysis, strain $\mathrm{AA}^{\mathrm{T}}$ is considered to represent a novel species of the genus Desulfoluna.

Strain $\mathrm{AAl}^{\mathrm{T}}$ was able to dehalogenate a wide range of brominated phenolic compounds (Table 2), namely 2BP, 3-bromophenol, 4-bromophenol, 2,6-dibromophenol, 2,4,6-tribromophenol, 3,5-dibromo-4-hydroxybenzoate, 2-iodophenol and 2-bromo-4-fluorophenol. Transformation of 3-bromophenol to phenol took much longer than for 2BP and for 4-bromophenol. During dehalogenation of 2BP, stoichiometric amounts of phenol accumulated (data not shown). Phenol was not utilized even after prolonged incubation. No transformation of $2 \mathrm{BP}$ occurred without lactate as electron donor, and lactate alone was not converted to acetate. These data indicate that strain $\mathrm{AA}^{\mathrm{T}}$ was able to respire and to grow via reductive dehalogenation of bromophenols. Strain $\mathrm{AA}^{\mathrm{T}}$ was able to dehalogenate $2 \mathrm{BP}$ in the presence of sulfate, and sulfate reduction occurred simultaneously, contributing to an increase in cell mass over that observed when $2 \mathrm{BP}$ was added as the only electron acceptor (data not shown). No bromobenzoate, monochlorophenol or fluorophenol isomers were dehalogenated. Interestingly, 2 - and 3-iodophenol were also dehalogenated by strain $\mathrm{AA}^{\mathrm{T}}$. Dehalogenation of iodophenols has previously been observed in co-cultures (Fennell et al., 2004) and sediment enrichment cultures (Häggblom \& Young, 1995). Similar to brominated compounds, iodinated organic compounds are also produced naturally by marine organisms (Faulkner, 1977; King, 1986). Reductive dehalogenation of organoiodine compounds is more likely than dehalogenation of organobromine or organochlorine compounds, because of the lower electron negativity of iodine. Bromophenol-dehalogenating micro-organisms in the marine environment appear to have cross-activity against iodinated compounds.

Strain $\mathrm{AA}^{\mathrm{T}}$ contained mainly even-numbered fatty acids, which is an indication of the use of acetyl CoA as a precursor for chain elongation during the synthesis of fatty acids (Taylor \& Parkes, 1983). The dominant cellular fatty acids were $\mathrm{C}_{14: 0}(6.1 \pm 0.3 \%$ of the total; mean \pm SD of three determinations), iso- $\mathrm{C}_{14: 0}(10.5 \pm 2.8 \%), \mathrm{C}_{14: 0} 3$ $\mathrm{OH}(14.9 \pm 2.7)$, iso- $\mathrm{C}_{15: 0}(1.9 \pm 0.2 \%)$, anteiso- $\mathrm{C}_{15: 0}$ $(11.6 \pm 0.5 \%) \mathrm{C}_{16: 0}(9.8 \pm 1.2 \%)$, iso- $\mathrm{C}_{16: 0}(2.3 \pm 0.1 \%)$

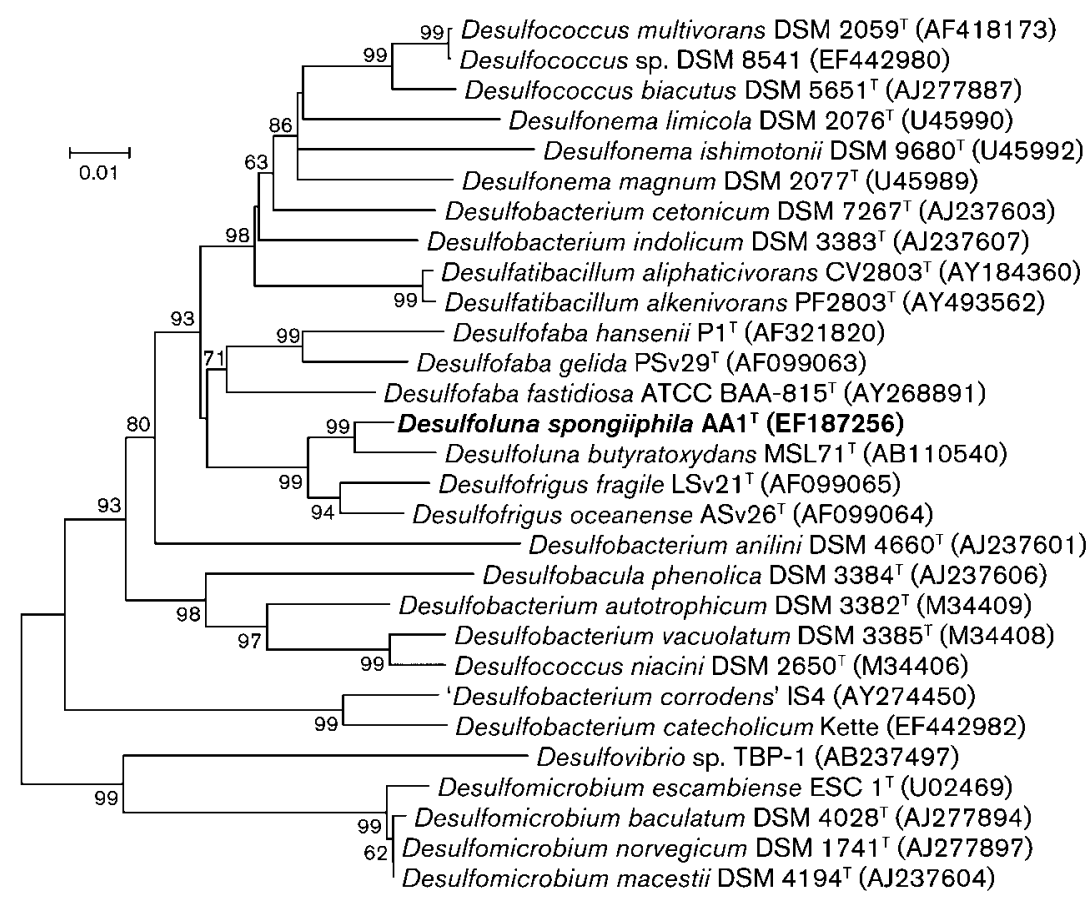

Fig. 2. Phylogenetic tree based on $16 \mathrm{~S}$ rRNA gene sequences showing the position of strain $A A 1^{\top}$ among related species in the Desulfobacteraceae. Bootstrap values above $50 \%$ are shown at nodes. Bar, 0.01 substitutions per 100 positions. 
Table 2. Dehalogenation of halogenated phenols and benzoates by strain $\mathrm{AA} 1^{\mathrm{T}}$

Strain $\mathrm{AAl}^{\mathrm{T}}$ was supplied with lactate and assayed after 30 days incubation at $28{ }^{\circ} \mathrm{C}$. Bromobenzoate, monochlorophenol and fluorophenol isomers were not dehalogenated.

\begin{tabular}{|ll|}
\hline Dehalogenation observed & \multicolumn{1}{c|}{ End product } \\
\hline 2-Bromophenol & Phenol \\
3-Bromophenol & Phenol \\
4-Bromophenol & Phenol \\
2,4-Dibromophenol & Phenol \\
2,6-Dibromophenol & Phenol \\
2,4,6-Tribromophenol & 4-Bromophenol, phenol \\
2-Iodophenol & Phenol \\
3-Iodophenol & Phenol \\
2-Bromo-4-fluorophenol & 4-Fluorophenol \\
3,5-Dibromo-4-hydroxybenzoate & 4-Hydroxybenzoate \\
\hline
\end{tabular}

$\mathrm{C}_{16: 1} \omega 7 c(17.0 \pm 2.6 \%)$ and $\mathrm{C}_{18: 1} \omega 7 c(23.8 \pm 0.9 \%)$. The fatty acid profiles of Desulfoluna butyratoxydans MSL71 ${ }^{\mathrm{T}}$, Desulfofrigus oceanense $\mathrm{ASv} 26^{\mathrm{T}}$ and Desulfofrigus fragile $\mathrm{LSv} 21^{\mathrm{T}}$, the closest phylogenetic relatives of strain $\mathrm{AA} 1^{\mathrm{T}}$, were distinctly different (Supplementary Table S1). In particular, two of the major fatty acids in strain $\mathrm{AAl}^{\mathrm{T}}$, iso$\mathrm{C}_{14: 0}$ and anteiso- $\mathrm{C}_{15: 0}$, were not reported in the above Desulfoluna and Desulfofrigus species.

Desulfofrigus species have been isolated from cold environments (Sahm et al., 1999; Knoblauch et al., 1999), whereas strain $\mathrm{AAl}^{\mathrm{T}}$ was from a subtropical area. Desulfoluna butyratoxydans $\mathrm{MSL71}^{\mathrm{T}}$ was isolated from estuarine sediment and the optimum growth temperature is $30{ }^{\circ} \mathrm{C}$ (Suzuki et al., 2008). In addition, Desulfoluna butyratox$y$ dans $\mathrm{MSL71}^{\mathrm{T}}$ is not able to dehalogenate 2,6-dibromophenol or to utilize citrate or glucose as electron donor, in contrast to strain $\mathrm{AAl}^{\mathrm{T}}$. On the basis of the phylogenetic, physiological and chemotaxonomic characteristics described here, strain $\mathrm{AAl}^{\mathrm{T}}$ is considered to represent a novel species of the genus Desulfoluna, for which the name Desulfoluna spongiiphila sp. nov. is proposed.

\section{Description of Desulfoluna spongiiphila sp. nov.}

Desulfoluna spongiiphila (spon.gi.i.phi'la. L. fem. n. spongia sponge; N.L. fem. adj. phila from Gr. philos friendly, loving; N.L. fem. adj. spongiiphila friendly to/living within a sponge).

Anaerobic, reductively dehalogenating, Gram-negative, short, curved rods. Uses sulfate, sulfite and thiosulfate as electron acceptors, in addition to halophenols. Propionate, lactate, pyruvate, succinate, citrate, benzoate and glucose are used as electron donors for dehalogenation of brominated phenolic compounds. The $\mathrm{G}+\mathrm{C}$ content of the genomic DNA of the type strain is $58.5 \mathrm{~mol} \%$. The predominant cellular fatty acids are $\mathrm{C}_{14: 0}$, iso- $\mathrm{C}_{14: 0}, \mathrm{C}_{14: 0}$ 3-OH, anteiso- $\mathrm{C}_{15: 0}, \mathrm{C}_{16: 0}, \mathrm{C}_{16: 1} \omega 7 c$ and $\mathrm{C}_{18: 1} \omega 7 c$.
The type strain, $\mathrm{AAl}^{\mathrm{T}}\left(=\mathrm{DSM} 17682^{\mathrm{T}}=\mathrm{ATCC}\right.$ BAA$\left.1256^{\mathrm{T}}\right)$, was isolated from a marine sponge from the Mediterranean Sea.

\section{Acknowledgements}

We thank Ute Hentschel for collaboration and providing sponge samples, Norberto Palleroni for advice on taxonomy and nomenclature, Valentine Starovoytov for electron micrographs, and Brandon Saks, Carrie Fraser and Lora McGuinness for assisting with technical analyses. This research was funded in part by the National Science Foundation (OCE-451708) and the Department of Defense Strategic Environmental Research and Development Program (ER-1492).

\section{References}

Ahn, Y.-B., Rhee, S.-K., Fennell, D. E., Kerkhof, L. J., Hentschel, U. \& Häggblom, M. M. (2003). Reductive dehalogenation of haloaromatics by microorganisms associated with the marine sponge Aplysina aerophoba. Appl Environ Microbiol 69, 4159-4166.

Altschul, S. F., Madden, T. L., Schäffer, A. A., Zhang, J., Zhang, Z., Miller, W. \& Lipman, D. J. (1997). Gapped BLAST and PSI-BLAST: a new generation of protein database search programs. Nucleic Acids Res 25, 3389-3402.

Ashworth, R. B. \& Cormier, M. J. (1967). Isolation of 2,6dibromophenol from the marine hemichordate, Balanoglossus biminiensis. Science 155, 1558-1559.

Baker, J. T. \& Duke, C. C. (1973). Isolation from the hypobranchial glands of marine molluscs of 6-bromo-2,2-dimethylthioindolin-3-one and 6-bromo-2-methylthioindoleninone as alternative precursors to Tyrian purple. Tetrahedron Lett 14, 2481-2482.

Boyle, A. W., Phelps, C. D. \& Young, L. Y. (1999). Isolation from estuarine sediments of a Desulfovibrio strain which can grow on lactate coupled to the reductive dehalogenation of 2,4,6-tribromophenol. Appl Environ Microbiol 65, 1133-1140.

Bozzola, J. J. \& Russell, L. D. (1992). Electron Microscopy. Principles and Techniques for Biologists. Boston: Jones and Bartlett.

Bradford, M. M. (1976). A rapid and sensitive method for the quantitation of microgram quantities of protein utilizing the principle of protein-dye binding. Anal Biochem 72, 248-254.

Breznak, J. A. \& Costilow, R. N. (1994). Physicochemical factors in growth. In Methods for General and Molecular Bacteriology, pp. 137154. Edited by P. Gerhardt, R. G. E. Murray, W. A. Wood \& N. R. Krieg. Washington, DC: American Society for Microbiology.

Ebel, R., Brenzinger, M., Kunze, A., Gross, H. J. \& Proksch, P. (1997). Wound activation of protoxins in marine sponge Aplysina aerophoba. J Chem Ecol 23, 1451-1462.

Faulkner, D. J. (1977). Interesting aspects of marine natural products chemistry. Tetrahedron 33, 1421-1443.

Felsenstein, J. (1993). PHYLIP (phylogeny inference package), version 3.5c. Distributed by the author. Department of Genome Sciences, University of Washington, Seattle, USA.

Fennell, D. E., Rhee, S.-K., Ahn, Y.-B., Häggblom, M. M. \& Kerkhof, L. J. (2004). Detecting the dehalogenating microorganism in a sulfidogenic, 2-bromophenol-utilizing enrichment by T-RFLP fingerprinting of ribosomes. Appl Environ Microbiol 70, 11691175.

Fielman, K. T., Woodin, S. A., Walla, M. D. \& Lincoln, D. E. (1999). Widespread occurrence of natural halogenated organics among temperate marine infauna. Mar Ecol Prog Ser 181, 1-12. 
Friedrich, M. W. (2002). Phylogenetic analysis reveals multiple lateral transfers of adenosine-5'-phosphosulfate reductase genes among sulfate-reducing microorganisms. J Bacteriol 184, 278-289.

Garson, M. J., Zimmermann, M. P., Battershill, C. N., Holden, J. L. \& Murphy, P. T. (1994). The distribution of brominated long-chain fatty acids in sponge and symbiont cell types from the tropical marine sponge Amphimedon terpenensis. Lipids 29, 509-516.

Gribble, G. W. (1999). The diversity of naturally occurring organobromine compounds. Chem Soc Rev 28, 335-346.

Häggblom, M. M. \& Young, L. Y. (1995). Anaerobic degradation of halogenated phenols by sulfate-reducing consortia. Appl Environ Microbiol 61, 1546-1550.

Hayt, M. A. (1981). Fixation for Electron Microscopy. New York. Academic Press.

Hentschel, U., Schmid, M., Wagner, M., Fieseler, L., Gernert, C. \& Hacker, J. (2001). Isolation and phylogenetic analysis of bacteria with antimicrobial activities from the Mediterranean sponges Aplysina aerophoba and Aplysina cavernicola. FEMS Microbiol Ecol 35, 305-312.

Hentschel, U., Fieseler, L., Wehrl, M., Gernert, C., Steinert, M. \& Hacker, J. (2003). Microbial diversity of marine sponges. In Sponges (Porifera) (Progress in Molecular and Subcellular Biology/Marine Molecular Biotechnology), pp. 59-88. Edited by W. E. G. Müller. Berlin \& Heidelberg: Springer.

King, G. M. (1986). Inhibition of microbial activity in marine sediments by a bromophenol from a hemichordate. Nature 323, 257259.

Knoblauch, C., Sahm, K. \& Jørgensen, B. B. (1999). Psychrophilic sulfate-reducing bacteria isolated from permanently cold arctic marine sediments: description of Desulfofrigus oceanense gen. nov., sp. nov., Desulfofrigus fragile sp. nov., Desulfofaba gelida gen. nov., sp. nov., Desulfotalea psychrophila gen. nov., sp. nov. and Desulfotalea arctica sp. nov. Int J Syst Bacteriol 49, 1631-1643.

Lane, D. J. (1991). 16S/23S rRNA sequencing. In Nucleic Acid Techniques in Bacterial Systematics, pp. 115-175. Edited by E. Stackebrandt \& M. Goodfellow. New York: Wiley.

Mesbah, M., Premachandran, U. \& Whitman, W. B. (1989). Precise measurement of the $\mathrm{G}+\mathrm{C}$ content of deoxyribonucleic acid by highperformance liquid chromatography. Int J Syst Bacteriol 39, 159-167.

Meyer, B. \& Kuever, J. (2007). Phylogeny of the alpha and beta subunits of the dissimilatory adenosine-5'-phosphosulfate (APS) reductase from sulfate-reducing prokaryotes - origin and evolution of the dissimilatory sulfate-reduction pathway. Microbiology 153, 20262044.

Monserrate, E. \& Häggblom, M. M. (1997). Dehalogenation and biodegradation of brominated phenols and benzoic acids under ironreducing, sulfidogenic, and methanogenic conditions. Appl Environ Microbiol 63, 3911-3915.

Murray, R. G. E., Doetsch, R. N. \& Robinow, C. F. (1994). Determinative and cytological light microscopy. In Methods for General and Molecular Bacteriology, pp. 21-41. Edited by P. Gerhardt, R. G. E. Murray, W. A. Wood \& N. R. Krieg. Washington, DC: American Society for Microbiology.
Norte, M. \& Fernández, J. J. (1987). Isolation and synthesis of aplysinadiene, a new rearranged dibromotyrosine derivative from Aplysina aerophoba. Tetrahedron Lett 28, 1693-1696.

Sahm, K., Knoblauch, C. \& Amann, R. (1999). Phylogenetic affiliation and quantification of psychrophilic sulfate-reducing isolates in marine arctic sediments. Appl Environ Microbiol 65, 3976-3981.

Schmitz, F. J. \& Gopichand, Y. (1978). (7E, 13 Dibromo-7,13,15-hexadecatrien-5-ynoic acid. A novel dibromo acetylenic acid from the marine sponge Xestospongia muta. Tetrahedron Lett 19, 3637-3640.

Song, B., Palleroni, N. J., Kerkhof, L. J. \& Häggblom, M. M. (2001). Characterization of halobenzoate-degrading, denitrifying Azoarcus and Thauera isolates and description of Thauera chlorobenzoica sp. nov. Int J Syst Evol Microbiol 51, 589-602.

Steward, C. C., Dixon, T. C., Chen, Y. P. \& Lovell, C. R. (1995). Enrichment and isolation of a reductively debrominating bacterium from the burrow of a bromometabolite-producing marine hemichordate. Can J Microbiol 41, 637-642.

Sun, B., Cole, J. R., Sanford, R. A. \& Tiedje, J. M. (2000). Isolation and characterization of Desulfovibrio dechloracetivorans sp. nov., a marine dechlorinating bacterium growing by coupling the oxidation of acetate to the reductive dechlorination of 2-chlorophenol. Appl Environ Microbiol 66, 2408-2413.

Suzuki, D., Ueki, A., Amaishi, A. \& Ueki, K. (2008). Desulfoluna butyratoxydans gen. nov., sp. nov., a novel Gram-negative, butyrateoxidizing, sulfate-reducing bacterium isolated from an estuarine sediment in Japan. Int J Syst Evol Microbiol 58, 826-832.

Taylor, J. \& Parkes, R. J. (1983). The cellular fatty acids of the sulphate-reducing bacteria, Desulfobacter sp., Desulfobulbus sp. and Desulfovibrio desulfuricans. J Gen Microbiol 129, 3303-3309.

Thompson, J. D., Gibson, T. J., Plewniak, F., Jeanmougin, F. \& Higgins, D. G. (1997). The CLUSTAL_X windows interface: flexible strategies for multiple sequence alignment aided by quality analysis tools. Nucleic Acids Res 25, 4876-4882.

Turon, X., Becerro, M. A. \& Uriz, M. J. (2000). Distribution of brominated compounds within the sponge Aplysina aerophoba: coupling of X-ray microanalysis with cryofixation techniques. Cell Tissue Res 301, 311-322.

Utkina, N. K., Denisenko, V. A., Scholokova, O. V., Virovaya, M. V., Gerasimenko, A. V., Popov, D. Y., Krasokhin, V. B. \& Popov, A. M. (2001). Spongiadioxins A and B, two new polybrominated dibenzo- $p$ dioxins from an Australian marine sponge Dysidea dendyi. J Nat Prod 64, 151-153.

Watson, J., Matsui, G. Y., Leaphart, A., Wiegel, J., Rainey, F. A. \& Lovell, C. R. (2000). Reductively debrominating strains of Propionigenium maris from burrows of bromophenol-producing marine infauna. Int J Syst Evol Microbiol 50, 1035-1042.

Weiss, B., Ebel, R., Elbrächter, M., Kirchner, M. \& Proksch, P. (1996). Defense metabolites from the marine sponge Verongia aerophoba. Biochem Syst Ecol 24, 1-12.

White, R. H. \& Hager, L. P. (1977). Occurrence of fatty acid chlorohydrins in jellyfish lipids. Biochemistry 16, 4944-4948. 